\title{
JNTIP
}

DOI : 10.24198/jnttip.v2i2.28561

Jurnal Nutrisi Ternak Tropis dan Ilmu Pakan

jurnal.unpad.ac.id/jnttip; e-ISSN:2715-7636

2(2):78-85, Juni 2020

\section{KONSEP BAHAN PAKAN PENGGANTI BEKATUL DALAM PAKAN ITIK HIBRIDA DENGAN TEPUNG BONGGOL PISANG (Musa paradiciasa $L$.) TERHADAP PENINGKATAN PERSENTASE KARKAS, ORGAN DALAM, DAN LEMAK ABDOMINAL}

\section{Concept Replacing Feeding of Rice Bran on Hybrid Duck With Hump Flour on Carcass Percentage, Internal Organ and Abdominal Fat}

\author{
Osfar Sjofjan, Danung Nur Adli, Farela Adhana Muflikhien
}

Fakultas Peternakan, Universitas Brawijaya, Malang, Jawa Timur 65145

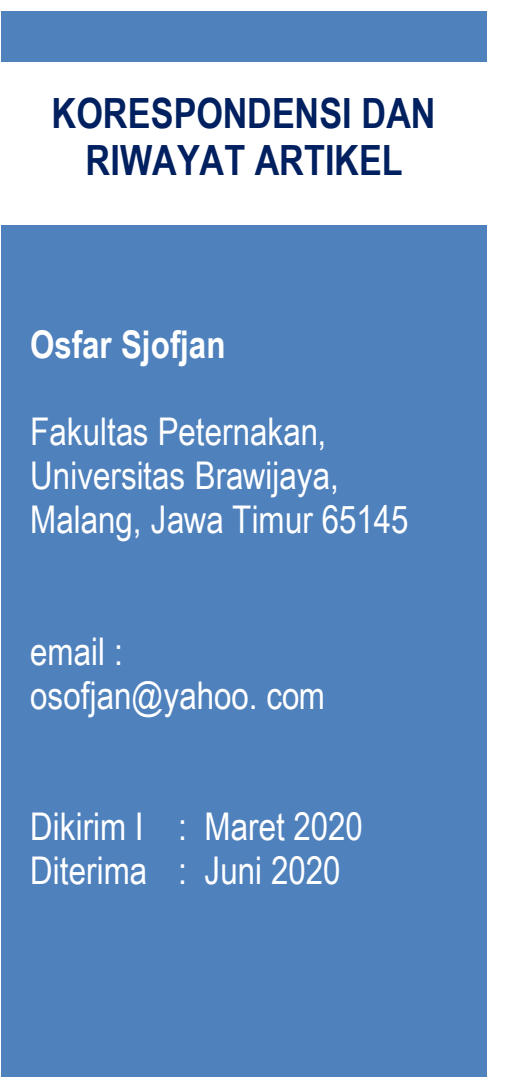

\begin{abstract}
ABSTRAK
Tujuan dari penelitian ini adalah untuk mengetahui persentase karkas, organ dalam, dan lemak abdominal itik pedaging. Materi penelitian adalah 100 ekor itik pedaging tanpa dibedakan jenis kelaminnya (umur 20 hari) dengan strain (Peking x Khaki Campbell) dengan rataan bobot badan yang digunakan adalah 410,52 \pm 95,25 g dengan koefisien keragaman sebesar 23,20 \%. Metode dalam penelitian ini adalah percobaan lapang dengan menggunakan Rancangan Acak Lengkap (RAL) yang terdiri dari 5 perlakuan 4 kali ulangan. Masing-masing ulangan 5 ekor itik pedaging. Perlakuan yang digunakan adalah P0: $10 \%$ bekatul, P1: 7,5\% $+2,5 \%$ tepung bonggol pisang, $\mathrm{P} 2: 5 \%+5 \%$ tepung bonggol pisang, P3: 2,5 \% + 7,5\% tepung bonggol pisang dan P4: 10 $\%$ tepung bonggol pisang. Variabel meliputi persentase karkas (dada, paha, sayap dan punggung), organ dalam (hati, jantung, limpa dan gizzard) dan persentase lemak abdominal. Data dianalisis menggunakan analisis kovarian (ancova). Apabila hasil penelitian menunjukan perbedaan nyata, maka dilanjutkan dengan Uji Jarak Berganda Duncan's. Hasil menunjukan bahwa tepung bonggol pisang memberikan pengaruh tidak nyata $(\mathrm{P}>0,05)$ terhadap persentase karkass,
\end{abstract} dan lemak abdominal tetapi memberikan pengaruh nyata $(\mathrm{P}<0,05)$ terhadap persentase gizzard. Berdasarkan hasil penelitian dapat disimpulkan bahwa penggunaan tepung bonggol pisang sebagai pengganti bekatul sampai dengan $10 \%$ dalam pakan memberikan hasil positif terhadap penampilan persentase karkas, serta mampu menguarangi kandungan lemak abdominal

Kata Kunci: Bonggol pisang; itik hibrida; karkas 


\section{ABSTRACT}

The purpose of this study was to determine the percentage of carcasses, internal organs, and abdominal fat of broiler ducks. The research material was 100 broiler ducks without distinguished sex (age 20 days) with strains (Peking x Khaki Campbell) with an average body weight used was $410.52 \pm 95.25 \mathrm{~g}$ with a coefficient of diversity of $23.20 \%$. The method in this study was a field experiment using a Completely Randomized Design (CRD) consisting of 5 treatments 4 replications. Each repetition of 5 broilers. The treatments used were P0: $10 \%$ rice bran, P1: $7.5 \%+2.5 \%$ banana weevil flour, P2: $5 \%+5 \%$ banana weevil flour, P3: $2.5 \%+$ $7.5 \%$ banana weevil flour and P4: $10 \%$ banana weevil flour. Variables include the percentage of carcasses (chest, thighs, wings and back), internal organs (liver, heart, spleen and gizzard) and the percentage of abdominal fat. Data were analyzed using analysis of covariance (ancova). If the research results show real differences, then proceed with Duncan's Multiple Multiple Test. The results showed that banana weevil had no significant effect $(P>0.05)$ on the percentage of carcass, and abdominal fat but had a significant effect $(P<0.05)$ on the percentage of gizzard. Based on the results of the study it can be concluded that the use of banana weevil flour as a substitute for rice bran up to $10 \%$ in feed gives positive results on the appearance of carcass percentage, and is able to reduce abdominal fat content

Keywords: Banana hump, hybrid duck, carcass

\section{PENDAHULUAN}

Peningkatan jumlah penduduk di Indonesia berdampak pada peningkatan kebutuhan protein hewani bagi penduduk Indonesia yang salah satunya dicukupi dengan protein ungags (Sjofjan et al., 2019) Pertumbuhan yang cepat dari ayam pedaging disebabkan karena perbaikan genetik dan pemberian pakan dengan kualitas pakan yang baik (Adli et al., 2019) Kualitas pakan salah satunya dipengaruhi oleh komposisi dan nutrisi dari bahan pakan. Salah satu bahan sumber protein yang biasa digunakan dalam formula pakan unggas yaitu bungkil kedelai, namun ketersediaannya masih terbatas dan sebagian besar masih mengandalkan hasil impor, sehingga menyebabkan harganya berfluktuatif sehingga mengakibatkan harga pakan jadi untuk ayam semakin membumbung tinggi (Adli et al., 2017). Salah satu upaya yang dapat dilakukan yaitu substitusi penggunaan bahan baku alternatif dengan menggunakan bahan pakan lokal yang mempunyai kandungan nutrisi yang yang hampir sama dan banyak dibudidayakan di Indonesia (Adli et al., 2018). Data statistik dari (Departemen Pertanian, 2017) menunjukkan bahwa populasi itik di Jawa Timur semakin meningkat setiap tahunnya. Pada tahun 2014 hingga 2017 pertambahan populasi itik sekitar 57.107-560.038 ekor, peningkatan populasi tertinggi terjadi pada tahun 2016. Meningkatnya populasi itik ini menunjukkan bahwa peternakan itik merupakan salah satu sektor yang semakin diminati dan berkembang di masyarakat. Itik merupakan ternak unggas yang dimanfaatkan daging dan telurnya. Pakan menjadi hal penting yang harus dipastikan selalu ada dan tercukupi setiap harinya dalam suatu usaha peternakan itik karena merupakan hal yang vital dan membutuhkan biaya besar. Biaya yang besar untuk menyediakan pakan menyebabkan perlu adanya pemanfaatan dari hasil samping yang ada di masyarakat baik dari limbah dapur, perkebunan maupun pertanian. Salah satu limbah perkebunan yang dapat dimanfaatkan yaitu bonggol pisang. Bonggol pisang merupakan bagian terbawah dari batang pohon pisang yang terletak didalam tanah. Bonggol pisang kepok (Musa paradiciasa L.) merupakan salah satu bagian yang belum dimanfaatkan oleh masyarakat. Oleh karena itu, perlu adanya pemanfaatan dari bonggol pisang ini 
sebagai pakan itik. Keuntungan penggunaan bonggol pisang adalah kandungan pati yang tinggi. Bonggol pisang memiliki komposisi berupa $76 \%$ pati, $20 \%$ air, sisanya adalah protein dan vitamin (Yuanita, dkk., 2008).

Tepung bonggol pisang mengandung karbohidrat sebesar $82,2 \%$ dan protein 5,88 $\%$ (Departemen Pertanian, 2017). Tepung bonggol pisang batu mengandung BK 92,64 $\%$, PK $1,71 \%$, LK 1,5 \%, SK 7,85 \%, abu $7,04 \%$, karbohidrat $89,75 \%$, tepung bonggol pisang kepok BK 91,56 \%, PK 1,72 \%, LK $1,15 \%$, SK 7,98 \%, karbohidrat 88,16\% (Aswandi, 2012). Kandungan karbohidrat yang tinggi dan pati sehingga akan memudahkan dalam proses pencernaan dalam ternak unggas. Namun, pakan ternak bersumber dari limbah perkebunan mempunyai nilai nutrisi yang rendah yaitu berupa serat kasar tinggi, energi metabolisme dan protein kasar yang rendah menjadi faktor pembatas dalam penggunaannya. Penelitian sebelumnya menjelaskan bahwa peningkatan kandungan serat kasar dalam pakan menyebabkan laju aliran digesta pakan dalam saluran pencernaan menjadi cepat (Handoko, dkk., 2013). Pemberian limbah pertanian tidak berpengaruh negatif terhadap pertumbuhan, konsumsi ransum dan Feed Convertion Ratio (Pasaribu, 2007). Pakan yang dikonsumsi oleh itik akan mempengaruhi persentase karkas pada saat panen. Bagian lain yang akan dipengaruhi oleh pakan sesuai dengan kualitas nutrisi yang terkandung dalam pakan yaitu, berat organ dalam itik yang terdiri dari hati, jantung, limpa dan gizzard (rempela) serta persentase lemak abdominal ternak. Berdasarkan uraian diatas, maka perlu dilakukan penelitian mengenai pengaruh dari pemberian tepung bonggol pisang sebagai pengganti bekatul dalam pakan itik hibrida terhadap persentase karkas, persentase organ dalam serta persentase lemak abdominal.

\section{METODE PENELITIAN}

\section{Materi Penelitian}

Materi penelitian yang digunakan pada penelitian ini adalah 100 ekor itik pedaging tanpa dibedakan jenis kelaminnya (unsex) dengan strain Hibrida persilangan dari itik Peking (jantan) dan Khaki Campbell (betina) yang telah berumur 20 hari dengan rataan bobot badan yang digunakan adalah 410,52 \pm 95,25 g dengan koefisien keragaman yaitu sebesar 23,20 \%. Itik Hibrida dibeli dari peternakan milik bapak Tito dengan harga 10.000/ ekor. Kandang yang digunakan menggunakan kandang panggung terdiri dari 20 flock. Setiap flock kandang diisi dengan 5

Tabel 1. Kandungan zat makanan bahan pakan dalam penelitian

\begin{tabular}{lllllll}
\hline Bahan Pakan & $\begin{array}{l}\text { Harga } \\
(\mathrm{Rp} / \mathrm{kg})\end{array}$ & $\begin{array}{l}\text { GE* } \\
(\mathrm{Kkal} / \mathrm{kg})\end{array}$ & $\begin{array}{l}\text { BK** } \\
(\%)\end{array}$ & $\begin{array}{l}\mathrm{PK}^{* *} \\
(\%)\end{array}$ & $\begin{array}{l}\text { SK** } \\
(\%)\end{array}$ & $\begin{array}{l}\mathrm{LK}^{* *} \\
(\%)\end{array}$ \\
\hline Jagung & 6000,00 & 2725,10 & 88,22 & 7,80 & 2,40 & 8,20 \\
Konsentrat & 6620,00 & 2700 & 88,93 & 41 & 5 & 5 \\
Bekatul & 2500,00 & 2315,60 & 90,35 & 10,37 & 26,50 & 3,74 \\
Tepung Bonggol & 1000,00 & 2244,20 & 91,91 & 2,15 & 12,36 & 1,00 \\
$\begin{array}{l}\text { Pisang (TBP) } \\
\text { Metionin }\end{array}$ & & & & & - & - \\
\hline
\end{tabular}

Keterangan: *Hasil analisis Laboratorium Pakan, Dinas Peternakan dan Perikanan, Kabupaten Blitar

**Hasil analisis Laboratorium Nutrisi dan Makanan Ternak Fakultas Peternakan Universitas Brawijaya (2018)

mempengaruhi pertumbuhan bobot badan dari ternak tersebut. Bobot badan itik merupakan faktor utama yang akan ekor itik Hibrida umur 20 hari, kandang dilengkapi dengan tempat minum dan tempat pakan. Pakan dan air minum yang digunakan 
Tabel 2. Susunan dan kandungan zat makanan bahan pakan periode finisher dalam penelitian

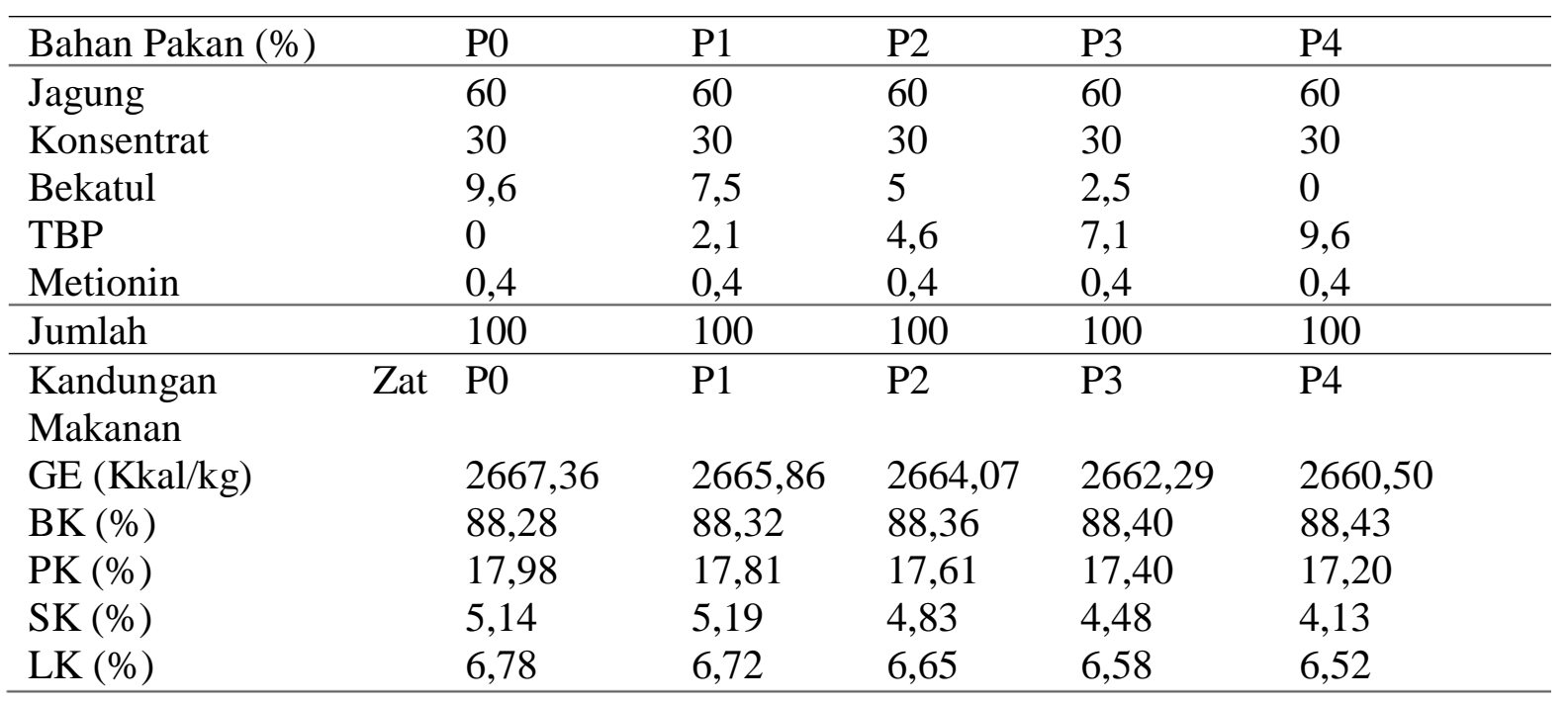

dalam penelitian diberikan secara ad libitum. Tepung bonggol pisang diperoleh dari bonggol pisang kepok yang melalui beberapa proses meliputi pencacahan bonggol pisang, pengeringan, dan penggilingan menjadi tepung.

Metode yang digunakan dalam penelitian ini adalah percobaan lapang dengan menggunakan Rancangan Acak Lengkap (RAL) yang terdiri dari 5 perlakuan 4 kali ulangan. Masing-masing ulangan 5 ekor itik pedaging. Perlakuan yang digunakan adalah :

P0 : Bekatul 10\%; P1 : Bekatul 7,5\% + tepung bonggol pisang 2,5 \%; P2: Bekatul $5 \%$ + tepung bonggol pisang $5 \%$; P3: Bekatul 2,5\% + tepung bonggol pisang 7,5\%; P4: Tepung bonggol pisang $10 \%$

\section{Analisis Statistika}

Data dianalisis menggunakan analisis kovarian (ancova). Apabila hasil penelitian menunjukan perbedaan nyata, maka dilanjutkan dengan Uji Jarak Berganda Duncan's. Data statistik dihitung dengan software SAS University Edition Red Hat 64 bit (Widiyawati, 2020).

\section{HASIL DAN PEMBAHASAN}

\section{Korelasi Pearson Two-Tailed}

Persentase karkas diperoleh dengan cara membandingkan bobot karkas dengan bobot hidup itik hibrida kemudian dikalikan dengan
$100 \%$. Bobot karkas merupakan bobot itik yang ditimbang setelah dipisahkan dengan bagian-bagian non karkas, seperti darah,

kepala, kaki (ceker), bulu serta seluruh isi rongga dada dan perut (Akhadiarto, 2010). Persentase bobot karkas itik pedaging pada umur 8 minggu berkisar 55,54 - 57,52\% (Rukmiasih, dkk, 2015). Menurut Sukirmansyah, dkk., (2016), persentase karkas dipengaruhi oleh bobot hidup, organ dalam, bagian yang terbuang serta kualitas pakan yang diberikan. Menurut Lestari, dkk, (2017), persentase karkas dipengaruhi oleh besarnya bobot potong dari itik hibrida. Hal ini disebabkan karena bobot karkas akan memberikan hasil yang selaras dengan bobot potong yang dihasilkan, sehingga semakin tinggi bobot potong maka semakin tinggi pula bobot karkasnya. Hasil analisis statistik dari persentase jantung yang tersaji dalam tabel 3 . menunjukkan bahwa pemberian TBP dalam pakan tidak berpengaruh nyata $(\mathrm{P}>0,05)$ terhadap persentase jantung, hati, limpa, gizzard, lemak abdominal itik hibrida. Hal ini diduga dikarenakan bobot hidup itik hibrida antar perlakuan memiliki bobot yang hampir sama. Faktor lain yang menyebabkan persentase jantung memiliki hasil yang tidak berpengaruh ini, diduga karena strain dari itik yang digunakan dalam penelitian merupakan strain yang sama, yaitu itik Hibrida dengan persilangan Itik Peking dan Itik Khaki Campbell. Menurut Ressang (2014), faktor 
yang memengaruhi bobot jantung yaitu bobot badan itik, umur, aktivitas itik dan juga jenis kelamin. Setiadi, Nova dan Tantalo, (2013) menyatakan bahwa, apabila aktivitas setiap hari yang dilakukan oleh ternak sama, maka akan memberikan pengaruh yang sama terhadap bobot jantung, hati, limpa, gizzard, bobot organ dalam dari itik mengalami peningkatan.

Berdasarkan pada Tabel 3. perlakuan P4 menunjukkan hasil paling rendah yaitu sebesar 59,65 $\pm 3,34 \%$. Pada perlakuan P4 ini TBP yang diberikan kepada itik dalam pakan sebanyak 10\%. Persentase karkas P4

Tabel 3. Rata-rata pengaruh perlakuan terhadap Persentase karkas, organ dalam dan lemak abdominal

\begin{tabular}{|c|c|c|c|c|c|}
\hline Variabel & $\mathrm{P} 0$ & $\mathrm{P} 1$ & $\mathrm{P} 2$ & P3 & $\mathrm{P} 4$ \\
\hline Bobot Karkas (g) & $\begin{array}{c}591,25 \pm \\
126,66\end{array}$ & $\begin{array}{c}618,25 \pm \\
32,62\end{array}$ & $\begin{array}{l}592,25 \pm \\
62,24\end{array}$ & $\begin{array}{l}720,5 \pm \\
133,51\end{array}$ & $\begin{array}{c}566,75 \pm \\
154,71\end{array}$ \\
\hline Persentase Karkas (\%) & $62,65 \pm 3,60$ & $62,89 \pm 1,64$ & $61,59 \pm 2,17$ & $63,39 \pm 1,35$ & $59,65 \pm 3,34$ \\
\hline Persentase Dada $(\%)$ & $21,95 \pm 7,41$ & $19,47 \pm 2,86$ & $22,21 \pm 2,57$ & $23,20 \pm 4,23$ & $19,25 \pm 2,30$ \\
\hline Persentase Paha (\%) & $26,48 \pm 3,27$ & $24,63 \pm 1,36$ & $25,49 \pm 1,11$ & $27,23 \pm 0,54$ & $27,97 \pm 2,41$ \\
\hline Persentase Sayap (\%) & $10,98 \pm 0,36$ & $11.12 \pm 1,69$ & $11,56 \pm 1,50$ & $11,01 \pm 0,58$ & $10,70 \pm 1,56$ \\
\hline $\begin{array}{l}\text { Persentase Punggung } \\
(\%)\end{array}$ & $40,59 \pm 5,90$ & $44,79 \pm 2,53$ & $40,74 \pm 2,63$ & $38,57 \pm 3,75$ & $42,09 \pm 2,89$ \\
\hline Persentase Hati (\%) & $3,62 \pm 0,94$ & $3,52 \pm 0,75$ & $3,52 \pm 0,68$ & $3,23 \pm 0,52$ & $3,49 \pm 0,58$ \\
\hline Persentase Jantung (\%) & $0,72 \pm 0,17$ & $0,73 \pm 0,03$ & $0,75 \pm 0,07$ & $0,63 \pm 0,06$ & $0,71 \pm 0,14$ \\
\hline Persentase Limpa (\%) & $0,14 \pm 0,03$ & $0,09 \pm 0,02$ & $0,14 \pm 0,04$ & $0,13 \pm 0,03$ & $0,16 \pm 0,09$ \\
\hline Persentase Gizzard (\%) & $3,81 \pm 0,34^{\mathrm{a}}$ & $4,16 \pm 0,36^{\mathrm{ab}}$ & $3,49 \pm 0,45^{\mathrm{a}}$ & $3,63 \pm 0,36^{\mathrm{ab}}$ & $4,55 \pm 0,35^{\mathrm{ab}}$ \\
\hline $\begin{array}{l}\text { Persentase Lemak } \\
\text { Abdominal (\%) }\end{array}$ & $1,89 \pm 0,63$ & $1,64 \pm 1,00$ & $1,14 \pm 0,76$ & $1,81 \pm 1,44$ & $2,14 \pm 0,68$ \\
\hline
\end{tabular}

Keterangan $\quad:{ }^{\mathrm{a}-\mathrm{b}}$ Super script yang berbeda pada baris yang sama menunjukkan adanya perbedaan yang sangat nyata $(\mathrm{P}<0,01)$

lemak abdominal (\%). Walaupun analisis statistik menunjukkan hasil yang tidak berpengaruh nyata, namun berdasarkan hasil rata-rata persentase karkas yang tersaji pada Tabel 3. perlakuan P3 $(63,39 \pm 1,35 \%)$ menunjukkan hasil perlakuan terbaik dibandingkan dengan perlakuan yang lainnya. Hal ini diduga disebabkan oleh bobot potong perlakuan P3 yang lebih tinggi pula dibandingkan dengan perlakuan yang lain. Hal tersebut didukung oleh pendapat Matitaputty, dkk., (2011), yang menyatakan bahwa karkas merupakan bagian tubuh yang pertumbuhan dan persentase terhadap bobot potong meningkat seiring dengan bertambahnya umur. Semakin tinggi bobot potong maka berpengaruh terhadap produksi karkas yang semakin meningkat. Menurut Saputra. dkk., (2016), persentase karkas menunjukkan hasil yang tidak nyata pada masing-masing perlakuan diduga karena yang rendah diduga karena kandungan ADF dalam TBP tinggi. Berdasarkan hasil analisis dari laboratorium Nutrisi dan Makanan Ternak (2018), diketahui bahwa kandungan ADF dari TBP sebesar 19,01\% $\pm 0,06$. Mangisah, Sukamto dan Nasution, (2009), menyatakan bahwa kadar ADF yang terlalu tinggi dalam pakan unggas dapat menurunkan kecernaan serat kasar dan protein kasar. Menurunnya kecernaan serat kasar dan bahan organik akan menurunkan pertumbuhan bobot badan, hal ini terjadi karena nutrisi yang diperlukan itik kurang tercukupi. Jaelani, Gunawan dan Syaifuddin, (2014) menjelaskan bahwa, karkas merupakan hasil utama dari suatu usaha peternakan. Persentase karkas yang tinggi akan menghasilkan daging yang tinggi pula, oleh karena itu pakan yang diberikan kepada ternak harus mengandung nutrient yang cukup sesuai kebutuhan ternak serta berkualitas. Persentase gizzard diperoleh 
dengan cara membandingkan bobot gizzard dengan bobot hidup, kemudian dikali $100 \%$. Pengambilan data bobot gizzard dilakukan dengan cara menimbang gizzard yang telah dibersihkan seluruh isinya. Gizzard merupakan organ dalam dengan ukuran terbesar yang berfungsi untuk mencerna atau menghancurkan makanan bertekstur kasar sebelum dicerna oleh usus (Resnawati, 2010; Mushawwir dkk., 2017; 2020a,b,c). Suryanah, Nur dan Anggraeni, (2016) menyatakan bahwa, bobot gizzard unggas dipengaruhi oleh bobot hidup, pakan yang dikonsumsi serta umur ternak. Penelitian yang telah dilakukan oleh Suparyanto (2004) menunjukkan bahwa rataan bobot gizzard kotor pada itik Peking X Alabio sebesar 60,36 g, sedangkan itik Peking $\mathrm{x}$ Mojosari menunjukkan rataan bobot gizzard kotor sebesar 52,07 g. Penelitian tersebut juga menunjukkan bahwa rataan bobot gizzard bersih dari itik Peking x Alabio sebesar 54,50 g dan itik Peking x Mojosari sebesar 46,20 g.

Hasil analisis statistika persentase gizzard yang tersaji pada Tabel 3 . menunjukkan bahwa pemberian TBP yang diberikan memberikan pengaruh sangat nyata $(\mathrm{P}<0,01)$ terhadap persentase gizzard. Hal tersebut diduga disebabkan karena adanya perbedaan aktivitas gizzard pada masingmasing perlakuan. Menurut Adli dan Sjofjan, (2020), bobot gizzard dipengaruhi oleh besar atau beratnya aktivitas gizzard yang terjadi saat mencerna pakan. Wiliyanti, dkk., (2017), menambahkan bahwa gizzard merupakan organ dalam yang terletak diantara proventrikulus dan batas atas usus halus. Otot yang terdapat dalam gizzard akan bekerja apabila terdapat pakan yang masuk kedalamnya. Pakan yang berjumlah banyak dengan tekstur yang keras dan kasar akan meningkatkan aktivitas gizzard (Mutaqin dkk., 2019; Susilawati dkk., 2019; Tanuwiria dkk., 2020). Aktivitas yang tinggi ini dapat meningkatkan bobot otot dan bobot gizzard pada itik Hibrida.

Berdasarkan rata-rata persentase gizzard (Tabel 3), diketahui bahwa persentase terbesar yaitu pada perlakuan $\mathrm{P} 4$ sebesar 4.55 \pm 0.35 , sedangkan persentase terkecil yaitu perlakuan P2 sebesar 3,49 \pm 0,45. Berdasarkan hal tersebut diduga perlakuan P4 dengan pemberian 10\% TBP lebih sulit dicerna oleh itik hibrida. Sehingga menyebabkan perlakuan $\mathrm{P} 4$ memiliki ratarata persentase gizzard tertinggi dibandingkan dengan perlakuan yang lainnya. Perlakuan terbaik yang diberikan kepada itik terhadap persentase gizzard ini dihasilkan oleh perlakuan P2 karena memiliki persentase bobot gizzard yang rendah. Hal ini menunjukkan bahwa kadar serat dalam pakan masih dapat dicerna oleh itik Hibrida, sehingga aktivitas gizzard dalam mencerna pakan tidak terlalu berat. Bobot organ gizzard yang dihasilkan selama penelitian masih normal karena menghasilkan rata-rata sekitar $3,49-4,55 \%$. Penelitian yang telah dilakukan oleh Putra dan Zulfikar (2017) dan Hernawan dkk. (2015) menunjukkan hasil bahwa rataan persentase bobot gizzard itik Peking sebesar $4,03-4,56 \%$.

\section{KESIMPULAN}

Penggunaan tepung bonggol pisang sebagai pengganti bekatul sampai dengan 10 $\%$ dalam pakan memberikan dalam pakan dapat memberikan hasil yang sama terhadap persentase karkas, organ dalam dan lemak abdominal, akan tetapi dapat meningkatkan bobot gizzard

\section{DAFTAR PUSTAKA}

Adli, D. N. and O. Sjofjan. 2018. Nutrient content evaluation of dried poultry waste urea molasses block (DPWUMB) on In-vitro analysis. Sains Peternakan, 16:50-53.

Adli, D. N. and O. Sjofjan. 2020. Growth performance, serum blood biochemistry, and intestinal properties of Arbor Acres Broiler fed diets containing mannan-riched fraction (MRF) and probiotic-enhanced liquid acidifier. Buletin Peternakan. 44:22-27.

Adli, D. N., Chi, Y., Lee, J. W. and O. Sjofjan. 2019. Supplementation Mannan-Rich Fraction (MRF) and/or 
Combination with Probiotic-Enhanced Water Acidifier on Dietary Female Broiler at 28 days as Natural Growth Promoters (NGPs). Research J. of Advanced Engineering and Science. 4: 427-429.

Adli, D. N., ).Sjofjan and M. Mashudi. 2017. Dried of poultry waste urea-molasses block (DPW-UMB) as potential for feed supplementation. J. Agripet. 17:44-149.

Adli, D. N., O. Sjofjan and M. Mashudi. 2018. Nutrient content evaluation of dried poultry waste urea-molasses block (DPW-UMB) on proximate analysis. J. Ilmu-Ilmu Peternakan, 28:84-89.

Adli, D. N., Sjofjan, O., and Mashudi, M. 2019. Nutrient content evaluation of dried of poultry waste urea-molasses block (DPW-UMB) on proximate analysis. J. Ilmu dan Teknologi Peternakan. 6:72-76.

Akhadiarto, S. 2010. Pengaruh pemberian probiotik temban, biovet dan biolacta terhadap persentase karkas, bobot lemak abdomen dan organ dalam ayam broiler. J. Sains Dan Teknologi Indonesia. 12:53-59.

Aswandi. 2012. Evaluasi sifat fisik dan kimia tepung bonggol dari berbagai varietas tanaman pisang. J. Triton. 3:25-32.

Departemen Pertanian. 2017. Prospek dan Arah Pengembangan Agribisnis Pisang. Badan Penelitian dan Pengembangan Pertanian. Departemen Pertanian. Jakarta.

Handoko, H., Nurhayati dan Nelwida. 2013. Penggunaan tepung kulit buah nanas dalam ransum terhadap bobot relatif organ pencernaan dan usus halus ayam pedaging yang disuplementasi yoghurt. J. Penelitian Universitas Jambi Seri Sains. 15:53-60.

Hernawan, E., L. Adriani, U.H. Tanuwiria. 2015. Dry matter digestibility, VFA and $\mathrm{NH}_{3}$ production in vitro of sheep rations supplemented sweet orange waste. Scientific Papers-Animal
Science Series: Lucrări Ştiinţifice Seria Zootehnie. 63:81-86.

Jaelani, A., A. Gunawan dan S. Syaifuddin. 2014. Pengaruh penambahan probiotik starbio dalam ransum terhadap bobot potong, persentase karkas dan persentase lemak abdominal ayam broiler. Ziraa'ah. 39:85-94.

Lestari, D., Rukmiasih, Suryati T., dan P. S Hardjosworo. 2017. Performa itik lokal (Anas platyrhynchos Javanica ) yang diberi tepung daun beluntas atau kenikir sebagai sumber pakan aditif. J. Ilmu Produksi Dan Teknologi Hasil Peternakan. 5:34-40.

Mangisah, I., B. Sukamto dan M. H. Nasution. 2009. Implementasi daun eceng gondok fermentasi dalam randum itik. J. Indon. Trop. Anim. Agric. 34:127-133.

Mushawwir, A., A.A. Yulianti, U.H. Tanuwiria, R. Wiradimadja, N. Suwarno. 2017. Adaptasi Metabolisme dan Alternatif Metabolisme Sumber Energi Otot Sapi Perah Terhadap Fluktuasi Mikroklimat Lingkungan Kandang. Prosiding Seminar Teknologi dan Agribisnis Peternakan V. 5:380385.

Mushawwir, A., A.A. Yulianti, N. Suwarno, R. Permana. 2020a. Profil metabolit plasma darah dan aktivitas kreatin kinase sapi perah berdasarkan fluktuasi mikroklimat lingkungan kandangnya. J. Veteriner. 21:24-30.

Mushawwir, A., N. Suwarno, D. Latipudin. 2020b. Profil metabolik jalur glikogenolisis puyuh dalam kondisi stres panas dengan pemberian diallyl $n$ sulfida (dn-s) organic. J. Galung Tropika. 9:48-59.

Mushawwir, A., N. Suwarno, R. Permana. 2020c. Profil non-esterified fatty acids (NEFA) dan trigliserida ayam sentul pada sistem pemeliharaan berbeda. J. Ilmu dan Industri Peternakan. 6:14-24.

Mutaqin, B.K., D. S. Tasripin, L. Adriani, U. H.Tanuwiria. 2019. effect of the addition of Ca-PUFA complexes to complete rations on fermentability and 
digestibility. Pakistan J. of Nutrition. 18:519-523.

Pasaribu, T. 2007. Produk Fermentasi Limbah Pertanian sebagai Pakan Unggas di Indonesia. WARTAZOA. $17: 1-8$.

Putra, H. S. S., dan Zulfikar. 2017. Penggunaan tepung ampas kecap asin pada itik peking terhadap perkembangan organ fisiologis. J. Ilmiah Peternakan. 5:66-70.

Ressang, A. A. 2014. Patologi Khusus Veteriner (Edisi ke-2). Denpasar, Bali: NV. Percetakan.

Saputra, Y. A., I. Mangisah dan B. Sukamto. 2016. Pengaruh penambahan tepung kulit bawang terhadap kecernaan protein kasar pakan, pertambahan bobot badan dan persentase karkas itik Mojosari. J. Ilmu-Ilmu Peternakan. 26: 29-36.

Setiadi, D., K. Nova, dan S. Tantalo. 2013. Pebandingan bobot hidup, karkas, giblet, dan lemak abdominal ayam jantan tipe medium dengan strain berbeda yang diberi ransum komersial broiler. J. Ilmiah Peternakan Terpadu. 1:25-31.

Sjofjan, O., D. N. Adli, P. K. Hanani, and D. Sulistiyaningrum. 2019. The utilization of bay leaf (Syzygium polyanthum Walp) flour in feed on carcass quality, microflora instestine of broiler. International $J$. of Engineering Technologies and Management Research. 6:1-9.

Sjofjan, O., D.N. Adli, M.H. Natsir, dan A. Kusumaningtyaswati. 2020. Pengaruh kombinasi tepung kunyit (curcuma domestica val.) dan probiotik terhadap penampilan usus ayam pedaging. J. Nutrisi Ternak Tropis dan Ilmu Pakan. 2:19-24.

Sukirmansyah, M. Daud, dan H. Latif. 2016. Evaluasi produksi dan persentase karkas itik peking dengan pemberian pakan fermentasi probiotik. J. IImiah Mahasiswa Pertanian Unsyiah. 1:719730 .
Suparyanto, A. 2004. Karakteristik ukuran organ dalam karkas itik genotipe peking $\mathrm{x}$ alabio dan peking $\mathrm{x}$ mojosar. Lokakarya Nasional Inovasi Teknologi Dalam Mendukung Usahaternak Unggas Berdayasaing. 1: 92-96.

Susilawati, I., N.P. Indriani, L. Khairani, U.H. Tanuwiria. 2019. Increase nutritional content and in vitro digestibility of forage legumes by adding molybdenum with foliar spray methods. Legume Research: An International J. 42: 31-42.

Tanuwiria, U.H., D. Tasrifin, A. Mushawwir. 2020. Respon gamma glutamil transpeptidase $(\gamma$-gt) dan kadar glukosa sapi perah pada ketinggian tempat (altitude) yang berbeda. J. Ilmu dan Industri Peternakan. 6:25-34.

Widiyawati, I., Sjofjan, O., dan Adli, D.N. 2020. Peningkatan kualitas dan persentase karkas ayam pedaging dengan subtitusi bungkil kedelai menggunakan tepung biji asam (Tamarindus indica 1) fermentasi. J. Nutrisi Ternak Tropis. 3:35-40.

Wiliyanti, N. K., N. W. Siti dan N. Witariadi. 2017. Pengaruh Penambahan Daun Pepaya Terfermentasi dalam Ransum terhadap Organ Dalam Itik Bali. J. of Tropical Animal Science. 5:131-145.

Yuanita, F., Ardeli, M., dan S. Muhammad. 2008. Pabrik sorbitol dari bonggol pisang (Musa paradisiacal) dengan proses hidrogenasi katalitik. J. Ilmiah Teknik Kimia ITS. 31:14-19. 